\title{
BLENDED LEARNING BERBASIS EDMODO: RESPON DAN PENERAPAN PADA MAHASISWA PENDIDIKAN MATEMATIKA
}

\author{
Sari Saraswati ${ }^{*}$, Iesyah Rodliyah ${ }^{2}$ \\ ${ }^{1,2}$ Universitas Hasyim Asy'ari Tebuireng Jombang \\ sarisaraswati7@gmail.com*1, iesyah_rodliyah@yahoo.co.id ${ }^{2}$ \\ *Corresponding Author
}

Received 25 October 2021; revised 30 November 2021; accepted 05 December 2021.

\begin{abstract}
ABSTRAK
Tujuan penelitian ini yaitu untuk mendeskripsikan penerapan dan respon mahasiswa terhadap pembelajaran blended learning berbasis Edmodo pada mata kuliah Kalkulus Dasar. Pengumpulan data penelitian ini menggunakan lembar angket, wawancara, serta dokumentasi. Data dianalisis secara kualitatif untuk mendeskripsikan bagaimana implementasi blended learning dengan platform Edmodo sebagai gabungan dari pembelajaran tatap muka dan online. Hasil analisis data menunjukkan bahwa pembelajaran blended learning yang diterapkan dapat membantu mahasiswa belajar materi dan latihan soal secara tuntas, mahasiswa dapat belajar secara mandiri di luar kelas, munculnya keaktifan mahasiswa dalam interaksi antara dosen dan mahasiswa. Secara umum, mahasiswa memberikan respon positif terhadap blended learning berbasis Edmodo yang diterapkan pada mata kuliah Kalkulus Dasar.
\end{abstract}

Kata kunci: blended learning, edmodo, implementasi, kalkulus dasar.

\begin{abstract}
The purpose of this study is to describe the application and response of students to Edmodobased blended learning in the Basic Calculus course. The data collection of this research used a questionnaire sheet, interviews, and documentation. The data was analyzed qualitatively to describe how the implementation of blended learning with the Edmodo platform was a combination of faceto-face and online learning. The results of data analysis show that the applied blended learning can help students learn the material and practice questions thoroughly, students can study independently outside the classroom, the emergence of student activity in interactions between lecturers and students. In general, students gave a positive response to the Edmodo-based blended learning applied to the Basic Calculus course.
\end{abstract}

Keywords: blended learning, edmodo, implementation, basic calculus. 


\section{Sari Saraswati, Iesyah Rodliyah}

\section{PENDAHULUAN}

Pada era 4.0 terjadi perkembangan TIK (Information and Communication Technology) yang memberikan dampak begitu besar dalam berbagai bidang kehidupan begitu pun bidang pendidikan. Akibatnya, dunia pendidikan dituntut untuk terus melakukan peningkatan kualitas serta penyesuaian terhadap penggunaan ICT dalam proses pembelajarannya (Nasrullah et al., 2017). Hal ini sependapat dengan Chaeruman (2018) yang menjelaskan bahwa salah satu yang harus dikuasai pada pembelajaran abad 21 yaitu keterampilan dalam segi informasi, tekonologi serta media.

Pembelajaran pada abad 21 mengharuskan para pendidik mampu menggunakan ICT agar pembelajarannya lebih fleksibel dan efektif. Pembelajaran di Perguruan Tinggi pun tidak terlepas dari pemanfaatan ICT supaya mahasiswa memiliki kecapakan dalam menghadapi tantangan pada abad 21. Sahid (2007) menjelaskan bahwa para dosen dapat memanfaatkan ICT untuk mengembangkan materi dan media pembelajaran dalam menghadapi kemajuan teknologi saat ini. Hal ini mendorong beberapa instansi dalam pendidikan termasuk Perguruan Tinggi untuk memanfaatkan sistem pembelajaran e-learning agar dapat meningkatkan pembelajaran yang fleksibel dan efektif (Maudiarti, 2018).

Namun faktanya pembelajaran berbasis IT masih belum banyak diterapkan oleh para pengajar di perguruan tinggi. Hal ini sejalan dengan pernyataan Agustin et al. (2020) bahwa tidak maksimalnya penggunanan teknologi dalam pembelajaran di perguruan tinggi disebabkan kurang meratanya sistem digitalisasi serta pakar di bidang teknologi pada suatu Program Studi tertentu. Pembelajaran berbasis IT masih dianggap sulit dalam penggunaannya. Berbagai alasan yang menyebabkan belum diterapkannya pembelajaran berbasis IT antara lain kurangnya waktu berlatih, kendala internet, minimnya waktu, kesulitan keuangan, (Brahim et al., 2014). Namun, di tengah maraknya COVID-19 dosen harus terus melakukan inovasi dalam mengemas pembelajaran kreatif, efektif dan efisien dengan memanfaatkan teknologi. Pada kondisi pandemi ini, pemerintah memutuskan kebijakan mengenai proses pembelajaran yang dilakukan dirumah secara jarak jauh atau daring. Dalam kondisi tersebut, banyak upaya yang dilakukan oleh dosen serta pendidik untuk tetap dapat melakukan perkuliahan secara optimal. Salah satunya 
dengan melakukan pembelajaran online. Namun, pada pelaksanaannya masih banyak dijumpai bahwa mahasiswa yang belum mampu menerima materi perkuliahan dengan cukup baik karena penyampaian materi yang singkat. Hasil penelitian Hutauruk \& Sidabutar (2020) menyebutkan bahwa dalam pembelajaran online, dosen cenderung hanya melakukan perkuliahan dengan membagikan daftar hadir dan modul saja. Selain itu, dalam pembelajaran mahasiswa hanya memperoleh sedikit penjelasan materi dan pemberian soal-soal latihan. Sedangkan pemahaman konsep mahasiswa pada perkuliahan bidang matematika sangat penting dilakukan salah satunya dalam mata kuliah Kalkulus.

Mata kuliah wajib yang harus ditempuh oleh mahasiswa khususnya pada Pendidikan Matematika yaitu Kalkulus Dasar, Kalkulus Lanjut dan Kalkulus Peubah Banyak. Materi kalkulus adalah materi yang membutuhkan perhatian cukup serius didalam pemilihan metode dan strategi pembelajaran, teknik pembelajaran serta penguasaan materi yang tepat. Namun faktanya banyak mahasiswa masih mengalami kesulitan dalam penguasaan materi kalkulus. Kesulitan mahasiswa dalam mempelajari kalkulus yang sering dijumpai yaitu kurang teliti dalam perhitungan, dan manajemen waktu kurang tepat saat menyelesaian latihan soal (Rejeki \& Setyaningsih, 2016). Disamping itu, Yenti (2016) menjabarkan bahwa keterbatasan waktu pembelajaran di dalam kelas menjadi salah satu penyebab kurang optimalnya pembelajaran kalkulus.

Proses pembelajaran di perguruan tinggi yang hanya dilakukan penyampaian materi saja menyebabkan terbatasnya komunikasi serta interaksi diantara dosen dan mahasiswa. Disamping itu, kurang optimalnya metode belajar praktik dibanding metode belajar teori. Namun, hal tersebut bisa disiasati dengan pemanfaatan e-learning dengan metode sinkronus dan asinkronus. Melalui metode sinkronus dan asinkronus dapat mengoptimalkan metode belajar praktik dibanding metode belajar teori (Farell et al., 2021). Pada metode sinkronus, mahasiswa dan dosen dapat saling berinteraksi dalam waktu bersamaan yang telah ditetapkan pada sebuah komunitas pembelajaran online dengan memanfaatkan teknologi dalam pembelajaran (Lewis \& Clarke, 2009). Sedangkan metode pembelajaran asinkronus adalah pembelajaran yang dapat diterapkan secara fleksibel karena tidak tergantung pada waktu, dan peserta didik dapat beriteraksisatu sama lain sesuai waktu yang 
ditentukan (Hosier, 2014). Melalui kedua metode tersebut mahasiswa mampu belajar dan berbagi ilmu dimanapun berada tanpa harus bertemu di tempat serta waktu yang sama.

Masa pandemi saat ini, Indonesia sudah mulai menerapkan kondisi new normal termasuk dalam dunia pendidikan. Oleh karena itu, para dosen serta pendidik perlu mempersiapkan proses pembelajaran dengan mencari cara yang efektif agar proses pembelajaran dapat berjalan baik. Salah satu upaya yang dapat diterapkan untuk mengoptimalkan pembelajaran adalah dengan menerapkan model pembelajaran blended learning (BL).

Graham (2006) menjelaskan bahwa Blended Learning (BL), merupakan: 1) gabungan dari strategi pembelajaran (combining instructional modalities or delivery media), 2) metode pembelajaran yang digabung (combining instructional methods), serta 3) gabungan dari dua pembelajaran tatap muka dan online (combining online and face-to-face instruction). Efektivitas dan fleksibillitas pembelajaran dengan memanfaatkan komputer dalam bentuk bentuk e-learning salah satunya adalah karena materi bisa diakses dimana pun serta kapan pun. Meskipun demikian, pembelajaran dalma bentuk e-learning dapat bersifat sebagai pelengkap dalam pembelajaran di kelas (face-to-face) agar tujuan pembelajaran bisa tercapai secara maksimal (Susilawati, 2017). Hal ini serupa dengan pernyataan Masie (2002) bahwa penerapan model blended learning tidak meninggalkan kegiatan tatap muka di kelas sehingga memungkinkan penggunaan sumber belajar online. Menurut Garrison \& Kanuka (2004), "blended learning is the thoughtful integration of classroom face-to-face learning experiences with online learning experiences". Penggabungan strategi dan metode pembelajaran dalam blended learning mampu mengoptimalkan terwujudnya tujuan pembelajaran (Istiningsih \& Hasbullah, 2015). Melalui pembelajaran berbasis blended learning ini mahasiswa dapat tetap melakukan kegiatan pembelajaran meskipun berada di tempat yang berlainan. Untuk itu perlu persiapan kegiatan pembelajaran yang tepat, materi yang mudah diakses, media yang mendukung, serta keluasan waktu bagi mahasiwa untuk belajar, latihan soal, dan mengakses sumber-sumber belajar. Platform pembelajaran yang bisa digunakan untuk menunjang penerapan blended learning salah satunya adalah Edmodo. 
Edmodo adalah salah satu platform pembelajaran e-learning yang berbentuk website. Banyak fitur yang disajikan oleh Edmodo sererti quiz, assignment, kalender, small group, serta badges. Edmodo juga bisa digunakan sebagai laman untuk upload penugasan, memberikan due date, serta memantau progress mahasiswa dalam penugasan. Edmodo dapat memuat bermacam bentuk media yang berupa tesk, suara, animasi, gambar, serta equation. Sebagai aplikasi e-Learning, Edmodo mudah digunakan karena tampilannya menyerupai facebook.

Keberhasilan penelitian ini dapat dilihat dari penelitian sebelumnya. Penelitian serupa dilakukan oleh Pertiwi et al. (2017) yang menunjukkan bahwa siswa menunjukkan sikap positif pada pembelajaran matematika yang menerapkan blended learning dengan memanfaatkan Edmodo. Namun, pada penelitian ini, model blended learning berbasis Edmodo diterapkan pada jenjang Perguruan Tinggi. Berdasarkan pemaparan tersebut, maka tujuan penelitian ini yaitu mendeskripsikan penerapan dan respon mahasiswa terhadap pembelajaran Kalkulus Dasar model blended learning dengan menggunakan Edmodo.

\section{METODE PENELITIAN}

Jenis dari penelitian yang digunakan adalah deskriptif kualitatif. Penelitian diawali dengan menerapkan blended learning sebanyak tiga kali pertemuan baik, selanjutnya diakhir pertemuan diberikan angket untuk mengetahui respon mahasiswa. Subjek dalam penelitian ini adalah mahasiswa Pendidikan matematika semester 1 dari Universitas Hasyim Asy'ari Tebuireng Jombang yang sedang menempuh mata kuliah Kalkulus Dasar yaitu sebanyak 13 mahasiswa. Keterbatasan subjek penelitian disebabkan karena jumlah mahasiswa dalam satu kelas hanya 13 orang.

Teknik pengumpulan data melalui lembar angket, interview serta dokumentasi. Data hasil angket digunakan untuk melihat bagaimana respon mahasiswa terhadap pelaksanaan blended learning berbasis Edmodo. Sedangkan data hasil wawancara digunakan untuk memperoleh informasi mendalam terhadap pelaksanaan pembelajaran dengan blended learning berbasis Edmodo. Data dianalisis secara deskriptif kualitatif untuk mengetahui respon mahasiswa terhadap pembelajaran pada mata kuliah Kalkulus Dasar dengan meimplementasikan bentuk 
blended learning berbasis Edmodo. Respon mahasiswa terkait penerapan blended learning dikatakan positif apabila rata-rata persentase pernyataan positif melebihi $80 \%$ terkait kesempatan belajar diluar kelas, keleluasan mengakses sumber belajar, antusias dan keaktifan selama kegiatan pembelajaran dengan menerapkan blended learning, serta kemandirian belajar.

\section{HASIL PENELITIAN DAN PEMBAHASAN}

Penelitian dilakukan untuk mendapatkan respon mahasiswa terhdap penerapan blended learning berbantukan aplikasi edmodo pada mata kuliah Kalkulus Dasar. Adapun hasil data diperoleh sebagai berikut.

\section{Penerapan Blended Learning Berbasis Edmodo}

Proses pembelajaran dalam penelitian yang dilakukan menggunakan gabungan antara pembelajaran online dan tatap muka. Desain pembelajaran yang dirancang terdiri dari 3 siklus kegiatan belajar. Sedangkan materi yang diajarkan fokus pada bab turunan (derivative). Materi ini merupakan inti dalam mata kuliah Kalkulus Dasar yang memiliki peran penting karena sebagai dasar dalam mengikuti perkuliahan Kalkulus Lanjut. Masing-masing kegiatan belajar yang dirancang menagacu pada silabus dan Rencana Pembelajaran Semester (RPS) yang terdiri dari beberapa kegiatan pembelajaran, yaitu:

1) memahami serta menganalisis konsep dasar turunan, differensial, serta nilai aproksimasi menggunakan konsep differensial.

2) Membuktikan teorema aturan pencarian turunan dan menggunakannya dalam menyelesaikan soal yang berkaitan dengan turunan.

3) Memahami konsep dasar aturan rantai serta derivatif tingkat tinggi dalam permasalahan serta menerapkannya dalam menyelesaikan soal turunan yang lebih kompleks.

Untuk mendukung maksimalnya pelaksanaan proses blended learning berbasis edmodo, maka disediakan media dalam pembelajaran tatap muka dan online. Perancangan sumber belajar pada pembelajaran tatap muka berupa Power Point serta Lembar Kerja Kelompok (LKK) untuk masing-masing kegiatan belajar. Sedangkan pada pembelajaran online masing-masing kegiatan belajar disusun bahan ajar berupa handout, video, serta sebuah soal yang bersifat open ended. Soal 
tersebut befungsi untuk mensinkronkan setiap kegiatan belajar sebelum tatap muka di kelas. Sedangkan handout yang diupload berisi penjabaran materi, rangkuman, contoh serta latihan soal.

Dalam mengawali kegiatan belajar (KB) dengan blended learning, sebelum kegiatan belajar 1, mahasiswa diberikan pengarahan terkait pengenalan platform pembelajatan yang digunakan yaitu edmodo, bagaimana cara registrasi akun, menginfokan kode kelas, serta teknis yang berkaitan dengan penerepan blended learning memakai edmodo. Hal ini bertujuan supaya mahasiswa dapat mengikuti siklus pembelajaran model blended learning dengan lancar. Adapun siklus tersebut disajikan pada Gambar 1 berikut.

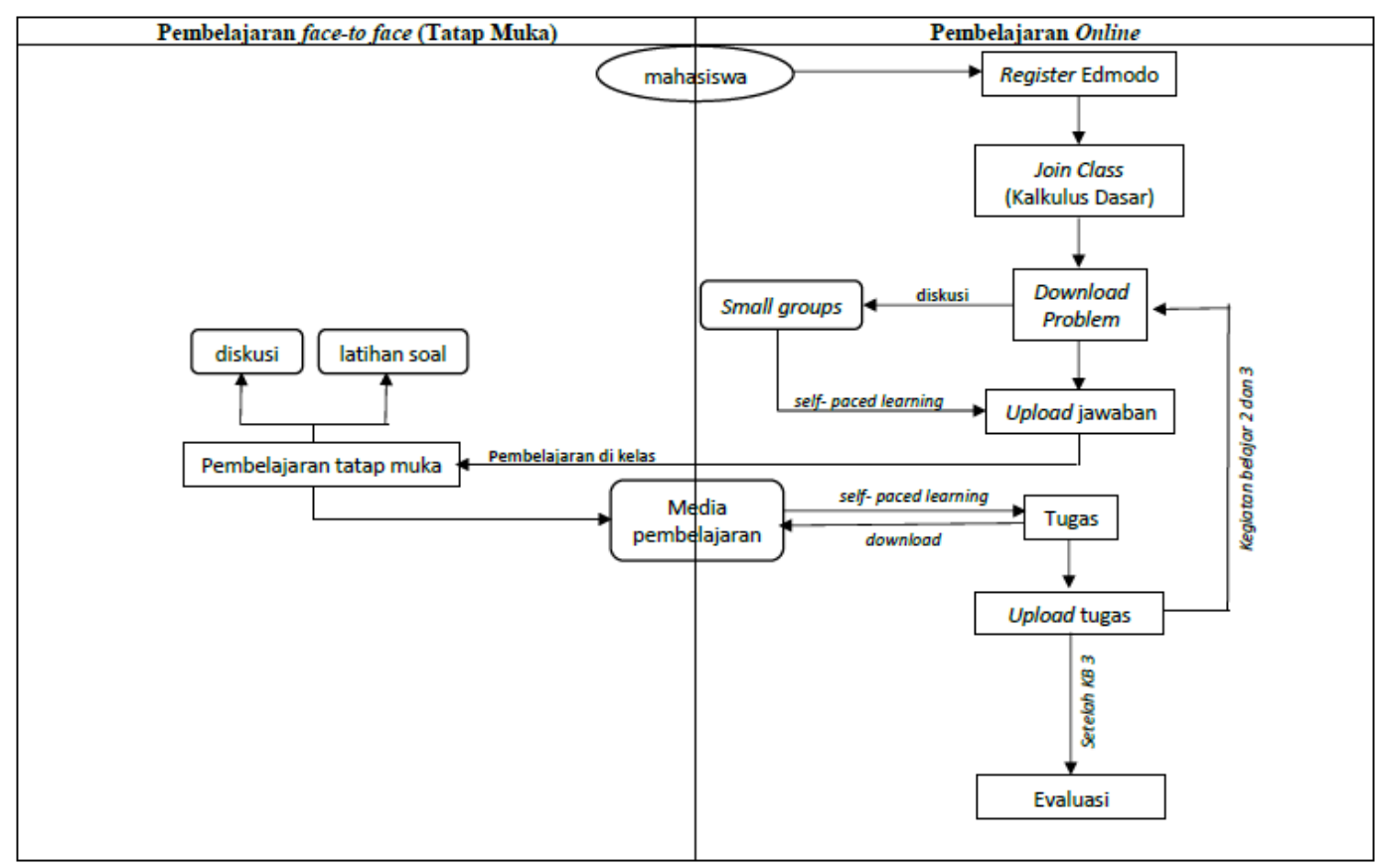

Gambar 1. Siklus pembelajaran blended learning berbasis edmodo

Berdasarkan gambar 1, dapat dilihat bahwa setelah mahasiswa registrasi akun edmodo maka mereka dapat bergabung (join class) pada kelas Kalkulus Dasar melalui kode kelas yang telah dibagikan sehingga dapat mengikuti siklus pembelajaran blended learning.

Adapun siklus kegiatan blended learning berbasis edmodo dijelaskan sebagai berikut:

1) Sebelum mengikuti pembelajaran tatap muka di kelas, mahasiswa diberikan permasalahan (problem) melalui edmodo. Problem yang diberikan merupakan 
soal open ended yang berkaitan dengan materi pada pertemuan tatap muka saat itu.

2) Membentuk mahasiswa dalam kelompok (small group) pada kelas Kalkulus Dasar di edmodo. Mahasiswa dapat mendownload problem yang diberikan dan mendiskusikan permasalahan yang diberikan bersama anggota kelompok masing-masing melalui edmodo. Mahasiswa memposting jawaban hasil diskusi pada halaman small group masing-masing.

3) Dosen melakukan pembelajaran tatap muka dikelas, membahas tentang problem yang telah didiskusikan oleh masing-masing kelompok melalui edmodo, dilanjutkan dengan menjelaskan materi pada pertemuan terkait. Dalam pembelajaran tatap muka, dosen membagikan LKK terkait materi yang diberikan kepada masing-masing kelompok. Membimbing diskusi kelompok, meminta perwakilan salah satu kelompok untuk mempresentasikan jawaban hasil diskusi. Sedangkan kelompok lainnya memberikan komentar atau masukan.

4) Dosen telah mempersiapkan latihan soal dan sumber belajar pada Edmodo sebelumnya. Lalu meminta mahasiswa membuka Edmodo untuk dapat mengakses latihan soal individu, handout, serta video pembelajaran terkait materi yang diberikan melalui edmodo dengan tujuan supaya mahasiswa dapat mempelajari ulang terkait materi yang telah dijelaskan. Mahasiswa diberikan kesempatan bertanya dan mendiskusikan latihan soal yang diberikan melalui Edmodo apabila mengalami kesulitan.

5) Pembelajaran selanjutnya berulang dari siklus (1) - (4). Pada akhir kegiatan belajar (KB) yang ke-3, mahasiswa diberikan tes melalui edmodo untuk mengukur ketercapaian hasil pembelajaran yang dilakukan.

Pada pelaksanaan perkuliahan dengan blended learning tidak banyak mengalami kesulitan dalam penerapannya. Mahasiswa sudah mampu beradaptasi dengan penggunaan aplikasi Edmodo walaupun baru pertama kali menggunakannya. Hal ini sesuai dengan Nasrullah et al. (2017) bahwa tampilan Edmodo seperti facebook sehingga mudah digunakan. Berikut ini tampilan pemberian informasi kegiatan pembelajaran pada edmodo. 

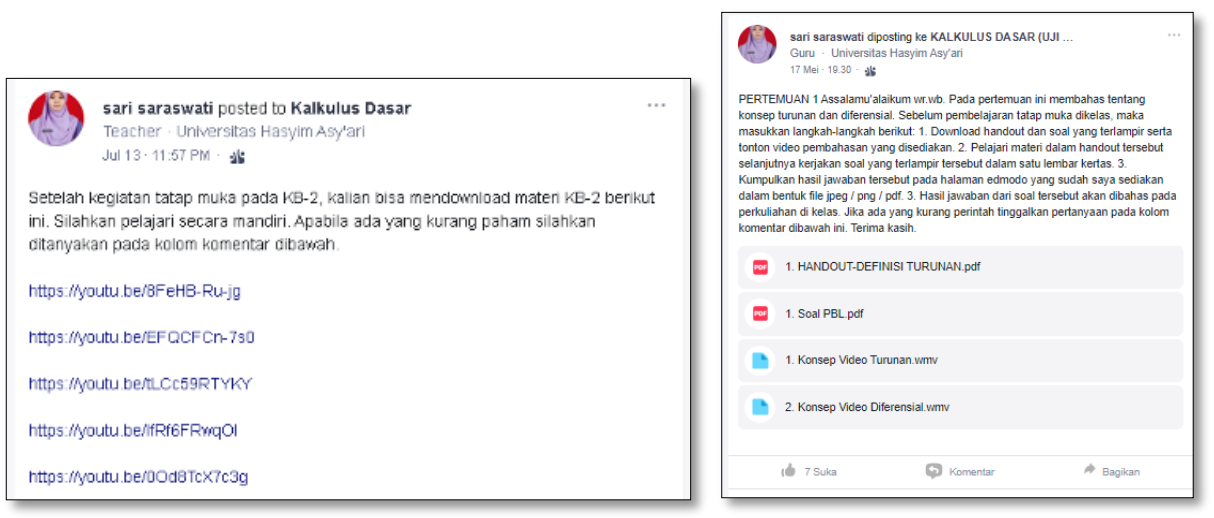

Gambar 2. Pemberian Bahan Ajar Online

Selain pemberian bahan ajar berupa Power Point, video, dan handout, pada setiap akhir kegiatan pembelajaran, mahasiswa diberikan tugas berupa latihan soal terkait materi yang telah dipelajari secara tatap muka. Tugas dapat diakses melalui Edmodo sehingga mereka dapat memiliki waktu dan kesempatan lebih lama untuk menyelesaiakannya. Berikut dapat dilihat pengumpulan tugas mahasiswa pada Gambar 3 berikut.

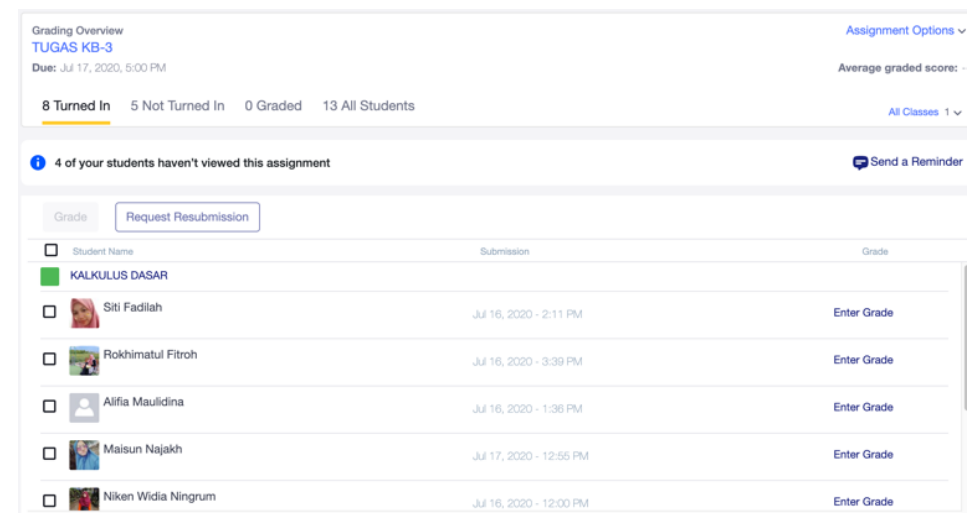

Gambar 3. Tampilan Pengumpulan Tugas Mahasiswa pada Edmodo

Dengan memberi peluang dan kesempatan yang lebih luas kepada mahasiwa dalam mengerjakan lebih banyak latihan soal diluar kelas, mereka menjadi terbuka untuk mendiskusikan permasalahan dan kesulitan yang dihadapi bersama dosen melalui Edmodo. Pembelajaran online berbasis Edmodo yang telah dirancang mampu memunculkan interaksi serta komunikasi lebih intens antara dosen dengan mahasiswa serta antar mahasiswa itu sendiri. Berikut ini hasil dokumentasi dari interaksi berikut yang terjadi dapat diperhatikan pada Gambar 2 dan 3. 

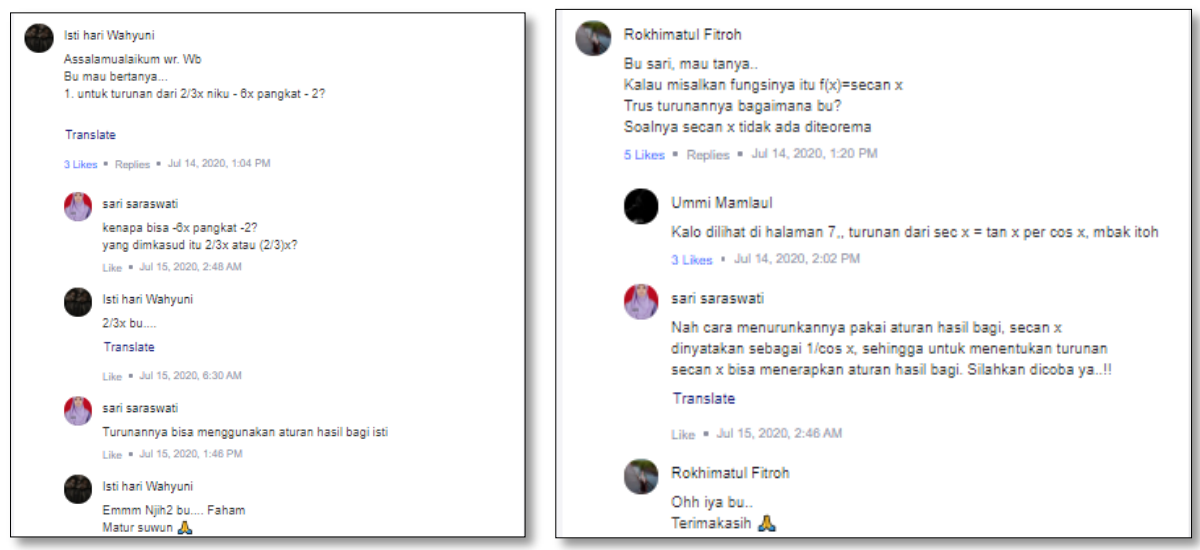

Gambar 4. Interaksi Dosen dan Mahasiswa
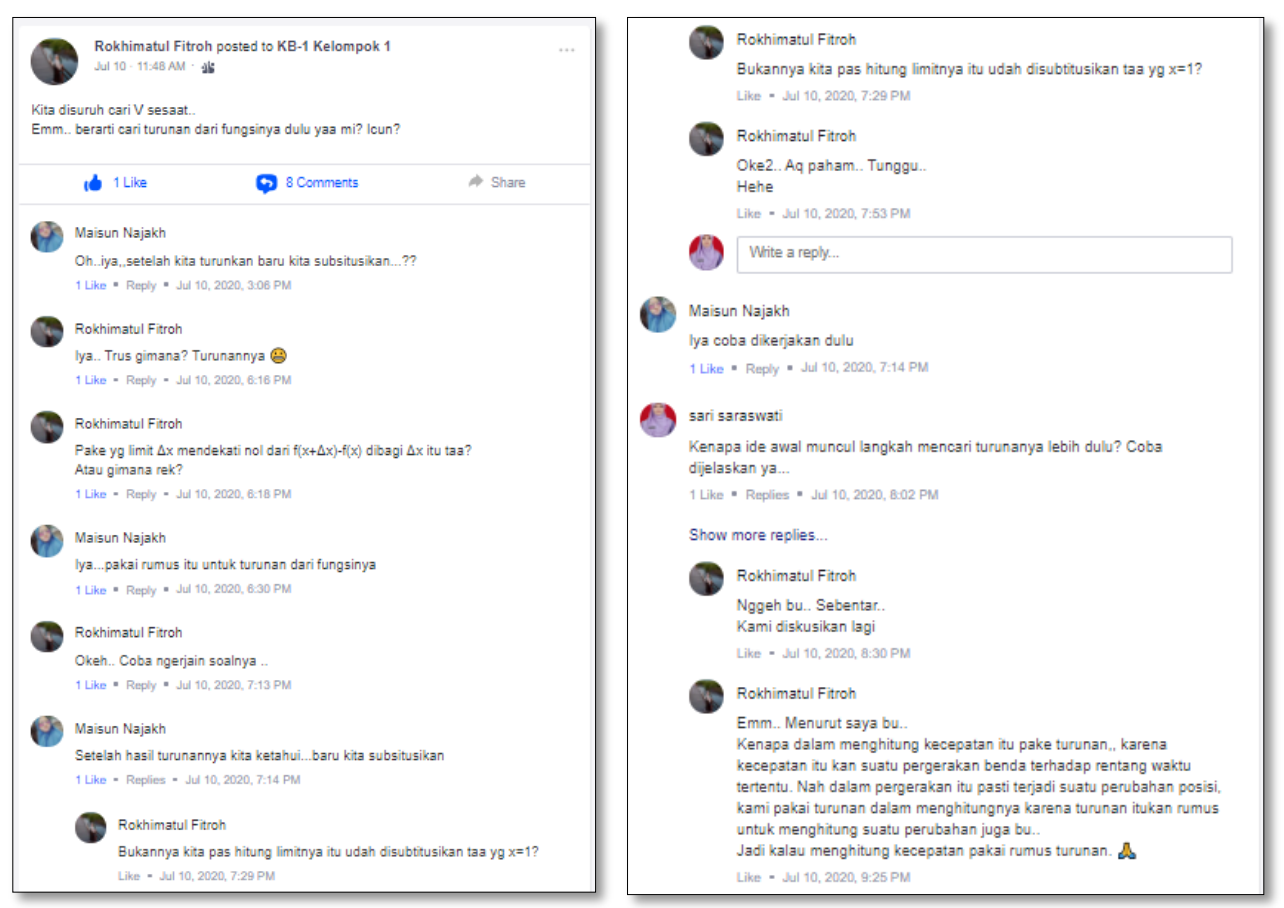

Gambar 5. Interaksi Mahasiswa Saat Diskusi Kelompok pada Kelas Kecil

Berdasarkan Gambar 4 dan 5 terlihat bahwa pembelajaran dengan model blended learning berbasis Edmodo yang diterapkan mampu memberikan kesempatan bagi mahasiwa untuk melakukan diskusi diluar kelas bersama dosen dan teman.

\section{Respon Mahasiswa terhadap Blended Learning Berbasis Edmodo}

Pada akhir kegiatan belajar ke-3, mahasiswa diberikan angket untuk mengetahui respon mereka terhadap terkait penerapan pembelajaran dengan model 
blended learning berbasis Edmodo. Data hasil angket mahasiswa disajikan pada Tabel 1 berikut:

Tabel 1. Interpretasi Respon Mahasiswa

\begin{tabular}{|c|c|c|}
\hline Aspek yang Dinilai & $\begin{array}{c}\text { Rata-rata } \\
\text { Presentase } \\
\text { penilaian }\end{array}$ & $\begin{array}{l}\text { Kategori } \\
\text { Respon }\end{array}$ \\
\hline $\begin{array}{l}\text { Kesempatan mahasiwa untuk bisa } \\
\text { mengerjakan latihan soal lebih luas } \\
\text { dan banyak di luar kelas }\end{array}$ & $88 \%$ & Positif \\
\hline $\begin{array}{l}\text { Keaktifan dalam pembelajaran } \\
\text { online dan offline }\end{array}$ & $82 \%$ & Positif \\
\hline $\begin{array}{l}\text { Antusias dan ketertarikan terhadap } \\
\text { materi perkuliahan }\end{array}$ & $82 \%$ & Positif \\
\hline $\begin{array}{l}\text { Pembelajaran yang menyenangkan } \\
\text { dan tidak membosankan }\end{array}$ & $85 \%$ & Positif \\
\hline $\begin{array}{l}\text { Kemudahan dalam mengakses } \\
\text { bahan ajar dan tugas }\end{array}$ & $91 \%$ & Positif \\
\hline Memfasilitasi belajar mandiri & $91 \%$ & Positif \\
\hline Rata-rata & $86,5 \%$ & Positif \\
\hline
\end{tabular}

Berdasarkan Tabel 1, terlihat hasil respon mahasiswa terhadap serangkaian penerapan pembelajaran blended learning yang dirancang memperoleh hasil positif karena respon mahasiswa masing-masing aspek mencapai nilai presentase $>80 \%$ yaitu mencapai rata-rata sebesar $86,5 \%$. Pembelajaran yang dikembangkan mengacu pada Graham (2006) yang mendefinisikan bahwa blended learning adalah penggabungan antara pembelajaran online dengan tatap muka. Oleh karena itu, serangkaian aktivitas yang dikembangkan harus mampu memfasilitasi pembelajaran secara efektif.

Hasil Tabel 1 menunjukkan bahwa respon mahasiswa terhadap penerapan blended learning mampu memfasilitasi mahasiswa dalam belajar secara mandiri yang mencapai 91\%. Hal ini sesuai dengan hasil penelitian Astuti \& Febrian (2019) yang menjelaskan bahwa pembelajaran berbentuk e-learning dapat membantu para mahasiswa mempelajari secara mandiri maupun kelompok dari materi yang diberikan. Selain itu dari Tabel 1 menunjukkan bahwa platform Edmodo yang digunakan membuat mahasiswa semakin aktif, antusias dan tertarik dalam belajar kalkulus dimana respon mahasiswa diperoleh $82 \%$. Hal ini sesuai dengan B 
Boholano (2017) yang memaparkan bahwa teknologi sebagai fasilitas yang mendukung pembelajaran lebih efektif.

Hasil angket menunjukkan bahwa respon mahasiswa positif terhadap ketuntasan materi yang diajarkan, kesempatan bertanya dan latihan soal diluar kelas, interaksi dengan dosen dan teman, kemudahan akses, pembelajaran menjadi aktif, menyenangkan dan tidak membosankan, serta terjadi interaksi antara dosen dan mahasiswa (Gambar 4 dan 5).

Selanjutnya mahasiswa diwawancara setelah meereka mengisi angket. Wawanacra dilakukan kepada 3 mahasiswa dari subjek penelitian untuk menegaskan isi hasil pengisian angket. Salah satu hasil wawancara tersebut bisa dilihat pada penggalan percakapan berikut:

Dialog 1

I : setelah mengikuti pembelajaran mulai pertama sampai akhir, apakah yang kamu rasakan?

S-1 : yaa... senang bu... hehehe... (tertawa)

I $\quad$ : apakah pembelajaran yang didesain itu membosankan?

S-1 : tidak bu, justru malah saya senang karena belum pernah diajar matematika dengan cara seperti ini.

I : apakah kamu memiliki kesempatan mengerjakan semua latihan soal yang diberikan?

S-1 : ya bu... saya mencoba semua latihan soalnya, tapi ada beberapa soal yang saya belum paham bu.

I : : kan bisa menanyakan kepada saya melalui edmodo.

S-1 : ya bu... hehehe.... (tertawa)

I $\quad$ : Dan disitu kan juga sudah ada handout yang berisi penjelasan materi beserta contoh soal, dan ada videonya juga. Apakah sumber belajar tersebut cukup membantunu belajar?

S-1 : Sangat membantu sekali bu... saya bisa mempelajari materi dan contoh soalnya dari situ bu. Dan saya juga bisa mengulang-ulang melihat videonya sampai saya paham bu, hehehe... (tertawa)

I $\quad$ : Alhamdulillah... tapi contoh - contoh soal dan materinya jelas apa tidak? 
S-1 : Cukup jelas bu... Cuma saya perlu banyak latihan bu, biar terampil seperti yang ibu bilang, hehehe...

Keterangan: I (Interviewer), S-1 (Subjek 1)

Hasil wawancara terhadap beberapa subjek penelitian tersebut diperoleh bahwa; 1) penerapan blended learning yang membuat pembelajaran menarik serta tidak membosankan bahwa lebih bersemangat dalam belajar. Ini sesuai dengan hasil penelitian Fahrurrozi \& Majid (2017) yaitu blended learning dengan platform edmodo dapat menumbuhkan semangat belajar mahasiswa, 2) mahasiswa memperoleh kebebasan dalam mengakses sumber dan bahan ajar ynag diberikan dengan dukungan jaringan internet yang bagus, 3) kesempatan untuk diskusi, tanya jawab serta mengerjakan latihan soal lebih luas.

\section{SIMPULAN}

Pembelajaran blended learning dengan fasilitas edmodo terdiri dari tiga siklus kegiatan belajar dimana masing-masing memuat pembelajaran online dan tatap muka. Dalam mendukung penerapan blended learning, maka disediakan media pembelajaran beruba handout, video pembelajaran, Lembar Kerja Kelompok (LKK), serta materi yang disajikan dalam power point. Secara umum, mahasiswa memberikan respon positif terhadap penerapan blended learning berbasis edmodo pada mata kuliah Kalkulus Dasar. Respon positif menunjukkan bahwa mahasiswa mendapat kesempatan lebih luas belajar diluar kelas, kemudahan dalam mengakses sumber belajar, keaktifan dan antusias mahasiswa terhadap pembelajaran dengan model blended learning, muncul interaksi antara dosen dan mahasiwa, serta menumbuhkan kemandirian dalam belajar.

\section{UCAPAN TERIMA KASIH}

Penulis menyampaikan banyak terima kasih terutama kepada Deputi RISBANG, RISTEK-BRIN atas dukungannya dalam kesuksesan penelitian ini serta dana penelitian yang diberikan melalui skema Penelitian Dosen Pemula (PDP) tahun 2020. 
DAFTAR PUSTAKA

Agustin, F., Oganda, F. P., Lutfiani, N., \& Harahap, E. P. (2020). Manajemen Pembelajaran Daring Menggunakan Education Smart Courses. Technomedia Journal, 5(1), 40-53. https://doi.org/10.33050/tmj.v5i1.1315

Astuti, P., \& Febrian, F. (2019). Blended Learning Syarah: Bagaimana Penerapan dan Persepsi Mahasiswa. Jurnal Gantang, 4(2), 111-119. https://doi.org/10.31629/jg.v4i2.1560

B Boholano, H. (2017). Smart Social Networkning: 21st Century Teaching and Learning Skills. Research in Pedagogy, 7(1), 21-29. https://doi.org/10.17810/2015.45

Brahim, N., Mohamed, B., Abdelwahed, N., Ahmed, L., Radouane, K., Khalid, S., \& Mohammed, T. (2014). The Use of the Internet in Moroccan High Schools Mathematics Teaching: State and Perspectives. Procedia - Social and Behavioral Sciences, 116(February 2014), 5175-5179. https://doi.org/10.1016/j.sbspro.2014.01.1095

Chaeruman, U. (2018). Pembelajaran Abad 21. Pembelajaran Abad 21, 1-24. http://simpatik.belajar.kemdikbud.go.id/uploads/materiseminar/Pembelajaran-di-Era Abad-21.pdf

Fahrurrozi, M., \& Majid, M. A. (2017). Pengembanggan Model Pembelajaran Blended Learning Berbasis Edmodo dalam Membentuk Kemandirian Belajar Siswa Pada Mata Pelajaran Ekonomi Kelas Xi Ips Sman 1 Selong Tahun Pelajaran 2017/2018. JPEK (Jurnal Pendidikan Ekonomi dan Kewirausahaan). https://doi.org/10.29408/jpek.v1i1.459

Farell, G., Simatupang, W., \& Giatman, M. (2021). Analisis Efektivitas Pembelajaran Daring pada SMK dengan Metode Asynchronous dan Synchronous. Edukatif: Jurnal Ilmu Pendidikan, 3(4), 1185-1190.

Garrison, D. R., \& Kanuka, H. (2004). Blended learning: Uncovering its transformative potential in higher education. Internet and Higher Education. https://doi.org/10.1016/j.iheduc.2004.02.001

Graham, C. R. (2006). Introduction to Blended Learning. Handbook of blended learning Global perspectives local designs. https://doi.org/10.2307/4022859

Hosier, A. (2014). Using Team-Based learning in an Online, Asynchronous Information Literacy Course. Katalog BPS, XXXIII(2), 81-87. http://www.americanbanker.com/issues/179_124/which-city-is-the-nextbig-fintech-hub-new-york-stakes-its-claim-1068345-

1.html\%5Cnhttp://www.ncbi.nlm.nih.gov/pubmed/15003161\%5Cnhttp://ci d.oxfordjournals.org/lookup/doi/10.1093/cid/cir991\%5Cnhttp://www.sciel o

Hutauruk, A., \& Sidabutar, R. (2020). Kendala pembelajaran daring selama masa pandemi di kalangan mahasiswa pendidikan matematika: Kajian kualiatatif deskriptif. Journal of Mathematics Education and Applied, 02(01), 45-51. https://jurnal.uhn.ac.id/index.php/sepren/article/view/364

Istiningsih, S., \& Hasbullah, H. (2015). Blended Learning, Trend Strategi Pembelajaran Masa Depan. Jurnal Elemen, 1(1), 49-56. https://doi.org/10.29408/jel.v1i1.79

Lewis, J., \& Clarke, A. D. M. (2009). Synchronous Learning and Web-Based Communication With Adobe Acrobat. Multimedia Information \& 
Technology, 34(4), 8-9.

Masie, E. (2002). Blended learning: The magic is in the mix. In The ASTD $e$ learning handbook (hal. 58-63).

Maudiarti, S. (2018). Penerapan E-Learning di Perguruan Tinggi. PERSPEKTIF Ilmu Pendidikan, 32(1), 53-68.

Nasrullah, A., Ende, E., \& Suryadi, S. (2017). Efektivitas Penggunaan Media Edmodo Pada Pembelajaran Matematika Ekonomi Terhadap Komunikasi Matematika. Symmetry: Pasundan Journal of Research in Mathematics Learning and Education, 2, 1-10. https://doi.org/10.23969/symmetry.v2i1.346

Pertiwi, A., Juariah, J., \& Kariadinata, R. (2017). Blended learning berbasis Edmodo pada kemampuan pembuktian matematis siswa. Jurnal Santika: Jurnal Imiah Sains dan Teknologi, 7(1), 579-584. https://doi.org/10.37150/jsa.v7i1.233

Rejeki, S., \& Setyaningsih, R. (2016). Kalkulus Integral Terhadap Hasil Belajar Mata. 63-70.

Sahid. (2007). Pengembangan Media Pembelajaran Berbasis ICT. Pendidikan Matematika FMIPA UNY, 1-16.

Susilawati, E. (2017). Developing Blended Learning Model on Civic Education Course. Edutech, 16(3), 288-304. http://ejournal.upi.edu/index.php/edutech/article/view/8181/pdf

Yenti, I. N. (2016). Hasil Perancangan Modul Kalkulus Dasar dan Lanjut dengan Menggunakan Maple 14. Ta'dib, 19(1), 49-60. https://doi.org/10.31958/jt.v19i1.450 